\title{
Article \\ Effects of Essential Oils from Cymbopogon spp. and Cinnamomum verum on Biofilm and Virulence Properties of Escherichia coli O157:H7
}

\author{
Raffaella Scotti $^{1}{ }^{(D}$, Annarita Stringaro ${ }^{2}\left(\mathbb{D}\right.$, Laura Nicolini ${ }^{1}$, Miriam Zanellato $^{3}$, Priscilla Boccia ${ }^{3}$, \\ Filippo Maggi ${ }^{4, *(D)}$ and Roberta Gabbianelli ${ }^{1}$ (D)
}

1 Biological Service, Italian National Institute of Health, 00161 Rome, Italy; raffaella.scotti@iss.it (R.S.); laura.nicolini@iss.it (L.N.); roberta.gabbianelli@iss.it (R.G.)

2 National Center for Drug Research and Evaluation, Italian National Institute of Health, 00161 Rome, Italy; annarita.stringaro@iss.it

3 Department of Technological Innovation and Safety of Plants, Product and Anthropic Settlements (DIT), Italian Workers' Compensation Authority (INAIL), 00143 Rome, Italy; m.zanellato@inail.it (M.Z.); p.boccia@inail.it (P.B.)

4 School of Pharmacy, University of Camerino, 62032 Camerino, Italy

* Correspondence: filippo.maggi@unicam.it; Tel.: +39-0737-404506

Citation: Scotti, R.; Stringaro, A.; Nicolini, L.; Zanellato, M.; Boccia, P.; Maggi, F.; Gabbianelli, R. Effects of Essential Oils from Cymbopogon spp. and Cinnamomum verum on Biofilm and Virulence Properties of Escherichia coli O157:H7. Antibiotics 2021, 10, 113. https://doi.org/ 10.3390/antibiotics10020113

Academic Editor: Carla Sabia Received: 28 December 2020

Accepted: 22 January 2021

Published: 25 January 2021

Publisher's Note: MDPI stays neutral with regard to jurisdictional claims in published maps and institutional affiliations.

Copyright: (C) 2021 by the authors. Licensee MDPI, Basel, Switzerland. This article is an open access article distributed under the terms and conditions of the Creative Commons Attribution (CC BY) license (https:// creativecommons.org/licenses/by/ $4.0 /)$.

\begin{abstract}
Every year, the pharmaceutical and food industries produce over 1000 tons of essential oils (EOs) exploitable in different fields as the development of eco-friendly and safe antimicrobial inhibitors. In this work we investigated the potential of some EOs, namely Cinnamomum verum, Cymbopogon martini, Cymbopogon citratus and Cymbopogon flexuosus, on the growth, biofilm formation and gene expression in four strains of enterohemorrhagic Escherichia coli O157:H7. All EOs were analyzed by gas chromatography-mass spectrometry (GC-MS). The antimicrobial activity was performed by using dilutions of EOs ranging from 0.001 to $1.2 \%(v / v)$. Subinhibitory doses were used for biofilm inhibition assay. The expression profiles were obtained by RT-PCR. E. coli O157:H7 virulence was evaluated in vivo in the nematode Caenorhabditis elegans. All EOs showed minimal inhibitory concentrations (MICs) ranging from 0.0075 to $0.3 \%(v / v)$. Cinnamomum verum bark EO had the best activity (MIC of $0.0075 \%(v / v)$ in all strains) while the C. verum leaf EO had an intermediate efficacy with MIC of $0.175 \%(v / v)$ in almost all strains. The Cymbopogon spp. showed the more variable MICs (ranging from 0.075 to $0.3 \%(v / v)$ ) depending on the strain used. Transcriptional analysis showed that C. martini EO repressed several genes involved in biofilm formation, virulence, zinc homeostasis and encoding some membrane proteins. All EOs affected zinc homeostasis, reducing $y k g \mathrm{M}$ and zin $\mathrm{T}$ expression, and reduced the ability of E. coli O157:H7 to infect the nematode C. elegans. In conclusion, we demonstrated that these EOs, affecting E. coli O157:H7 infectivity, have a great potential to be used against infections caused by microorganisms.
\end{abstract}

Keywords: Escherichia coli O157:H7; Cymbopogon spp.; Cinnamomum spp.; essential oils; antibacterial activity; biofilm; Caenorhabditis elegans model

\section{Introduction}

Bacterial infections are becoming a serious healthcare challenge because of the increased dissemination of multi-drug resistant bacteria. In the European Union multidrug resistant infections are responsible for approximately 25,000 patient deaths per year [1]. This increasing resistance of microorganisms to conventional drugs has induced scientists to search for novel substances with antimicrobial activity and with possible minor sideeffects. The persistence and the resistance of bacteria to disinfection are often associated with bacterial ability of aggregating to form a biofilm, a complex multicellular community of microorganisms. Biofilm is the predominant lifestyle of bacteria in all environments [2], and is more resistant to antibiotics and disinfectants $[3,4]$. 
Enterohemorrhagic Escherichia coli O157:H7 (EHEC) is a human pathogen, belonging to the attaching and effacing (A/E) E. coli group. It possesses virulence factors essential for adhesion to intestinal epithelial cells (attachment) and responsible for the destruction of the brush border of microvilli (effacement) [5]. This pathogen can cause bloody diarrhea hemorrhagic colitis and approximately four percent of the cases develop hemolytic uremic syndrome (HUS). The use of antibiotics in EHEC infections should be avoided because they induce the SOS response and activate prophages with the release of Shiga toxins [6]. The ability of E. coli O157:H7 to adhere and form biofilm on different surfaces, and the absence of effective therapy against EHEC infections have led to developing new antimicrobial agents. In the last years, there has been an increased interest in the study of natural products as possible therapeutic agents, with a particular attention to essential oils (EOs), chemical mixtures produced by the so-called aromatic plants that are known to be active against a wide variety of microorganisms [7]. EOs are complex hydrophobic and volatile liquids containing multiple low molecular weight compounds, including especially monoterpenoids and sesquiterpenoids, but also phenylpropanoids and aliphatic compounds [8]. EOs contain also minor constituents that can inhibit the growth of bacteria and have a synergistic or additive activity to that of major EO components $[9,10]$.

The EOs from cinnamon (Cinnamomum verum J. Presl), lemongrass (Cymbopogon citratus DC. Stapf and C. flexuosus (Nees ex Steud.) W. Watson) and palmarosa (C. martini (Roxb.) W. Watson) are produced in high quantity by the industry (between 50 and 100 tons/year) and are potentially exploitable in different fields. Notably, their antimicrobial activities are widely recognized and documented by the scientific community [11-14]. Indeed, EOs have previously shown a great potential against gastrointestinal and other pathogens [15-17]. Although plant extracts and EOs have been shown to have anti-E. coli O157:H7 activity $[9,16,18]$, comparative studies of the effects of EOs in E. coli EDL933 reference strain and in clinical human isolated from patients are limited. Here we focused on the five most promising EOs, chosen from a panel of ten EOs used in a first screening to test the inhibition of biofilm in different $E$. coli strains.

The aim of this study was to investigate the antibacterial and antibiofilm activities of five EOs, namely those obtained from bark and leaves of $C$. verum and from C. citratus, C. flexuosus and C. martini, on several E. coli O157:H7 strains and to explore the possible targets of their action. Thus, we analyzed the expression of genes related to biofilm formation and pathogenesis in E. coli. Since gene expression studies conducted on E. coli cells treated with $C$. martini are not known, we initially investigated the transcription levels of genes involved in motility $(\operatorname{csg} \mathrm{A}, f l i \mathrm{~A}$ and $\operatorname{fim} \mathrm{A})$, virulence $(s t x 2$ and $e h a \mathrm{~A})$, synthesis of membrane proteins (agn43, omp A and $p g a \mathrm{~A})$ and zinc homeostasis $(y \mathrm{kgM}$ and $z i n \mathrm{~T})$ in strains grown in the presence of $C$. martini. Finally, we also analyzed the transcription levels of $y \mathrm{kgM}$ and $z i n \mathrm{~T}$ in cells treated with the other EOs. Furthermore, an in vivo Caenorhabditis elegans model $[19,20]$ was used to study the effects of the EOs on the infection capacity of E. coli O157: H7.

\section{Results and Discussion}

\subsection{Chemical Components of Essential Oils}

The chemical compositions of the five EOs, as determined by GC-MS analysis, are reported in Supplementary Materials (Figure S1) and the main components are illustrated in Table 1. The analysis of EO chemical constituents (Supplementary Materials Table S1) showed that the main components were oxygenated monoterpenes and phenylpropanoids for Cymbopogon spp. and C. verum EOs, respectively. The main compounds of lemongrass EOs, which are represented by the species $C$. citratus and C. flexuosus, were the monoterpene aldehydes neral ( $32.0 \%$ and $30 \%$, respectively) and geranial $(48.2 \%$ and $41.5 \%$, respectively). Their mixture is commonly named citral [21]. C. martini EO was characterized by the monoterpene alcohol geraniol $(82.2 \%)$ and its ester geranyl acetate $(11.1 \%)$. The $C$. verum bark and leaf EO compositions were dominated by the phenylpropanoids (E)-cinnamaldehyde (85.4\%) and eugenol (83.5\%), respectively. Geraniol and citral were 
reported as active antimicrobial agents due to their functional groups and to their affinity for microbial membranes, that they traverse interacting with vital metabolic enzymes $[8,22]$. It was reported that $(E)$-cinnamaldehyde is one of the most potent natural antibacterial substances [23,24]. Its action, as well as that of eugenol, is conferred by free aldehyde and hydroxyl groups $[25,26]$. These are highly reactive and form hydrogen bonds with the active site of target enzymes, inactivating them $[27,28]$, and with the cell membrane, damaging it $[8,29]$. Although percentages of tested EOs differed in some degree from those previously reported, the main components were the same [30-35]. It is known that the different $\mathrm{EO}$ extraction methods, cultivation geographical region and climatic conditions can be responsible for these variations $[1,31]$.

Table 1. The main components present in the tested essential oils (Eos) at relative percentages higher than one percent.

\begin{tabular}{cl}
\hline EO & \multicolumn{1}{c}{ Main Components } \\
\hline Cymbopogon flexuosus & $\begin{array}{l}\text { geranial }(41.5 \%), \text { neral }(30.0 \%), \text { geranyl acetate }(6.1 \%), \text { geraniol } \\
(5.5 \%), \text { caryophyllene oxide }(2.8 \%), \gamma \text {-cadinene }(2.6 \%)\end{array}$ \\
\hline Cymbopogon citratus & $\begin{array}{l}\text { geranial }(48.2 \%), \text { neral }(32 \%), \text { geranyl acetate }(3.8 \%), \text { geraniol } \\
(3.1 \%), \text { camphene }(1.9 \%),(E) \text {-caryophyllene }\end{array}$ \\
\hline Cymbopogon martini & $\begin{array}{l}\text { geraniol }(82.5 \%), \text { geranyl acetate }(11.1 \%),(E) \text {-caryophyllene } \\
(2.2 \%), \text { linalool }(2.1 \%)\end{array}$ \\
\hline Cinnamomum verum (bark) & $\begin{array}{l}(E) \text {-cinnamaldehyde }(85.4 \%), \text { eugenol }(7.0 \%),(E) \text {-cinnamyl acetate } \\
(4.5 \%)\end{array}$ \\
\hline \multirow{2}{*}{ Cinnamomum verum (leaf) } & $\begin{array}{l}\text { eugenol }(83.5 \%), \text { benzyl benzoate }(2.9 \%),(E) \text {-caryophyllene } \\
(2.8 \%), \text { eugenol acetate }(1.9 \%), \alpha \text {-humulene }(1.2 \%),(E) \text {-cinnamyl } \\
\text { acetate }(1.2 \%)\end{array}$ \\
\hline
\end{tabular}

\subsection{Antibacterial and Antibiofilm Activity of EOs}

EOs exhibited remarkable in vitro antibacterial activity against all strains tested, as indicated in the results of the MIC determination (Table 2). The planktonic growth curves (data not shown) of examined strains indicated MIC values varying from $0.075 \%$ to $0.3 \%$ depending on EO and strain used. C. verum bark EO had the strongest inhibitory effect, showing a value of MIC of $0.0075 \%$ in all strains. The ED597 was more sensitive to the assayed EOs than the other strains, while the $\mathrm{K} 12$ was poorly sensitive to the EOs treatment. Minimal bactericidal concentration (MBC) values were above MIC values for most EOs (between $2 \times$ MIC and $4 \times$ MIC), while for the $C$. verum bark EO they were even $10 \times$ MIC. Only the $C$. verum leaf EO, MIC and MBC values were not very different.

Table 2. Minimum inhibitory and bactericidal concentration of EOs against $E$. coli strains. The results shown are in percentage $(v / v)$ and from three independent experiments.

\begin{tabular}{cccccccccccc}
\hline Strain/EO & C. flexuosus & \multicolumn{2}{c}{ C. citratus } & \multicolumn{2}{c}{ C. martini } & \multicolumn{2}{c}{ C. verum (Bark) } & \multicolumn{2}{c}{ C. verum (Leaf) } \\
\hline \multirow{2}{*}{ EDL933 } & MIC & 0.075 & MIC & 0.075 & MIC & 0.100 & MIC & 0.0075 & MIC & 0.175 \\
& MBC & 0.400 & MBC & 0.200 & MBC & 0.400 & MBC & 0.0800 & MBC & 0.200 \\
\hline \multirow{2}{*}{ ED597 } & MIC & 0.075 & MIC & 0.075 & MIC & 0.075 & MIC & 0.0075 & MIC & 0.150 \\
& MBC & 0.300 & MBC & 0.200 & MBC & 0.300 & MBC & 0.0200 & MBC & 0.200 \\
\hline \multirow{2}{*}{ EDB } & MIC & 0.075 & MIC & 0.200 & MIC & 0.100 & MIC & 0.0075 & MIC & 0.175 \\
& MBC & 0.400 & MBC & 0.400 & MBC & 0.200 & MBC & 0.0600 & MBC & 0.200 \\
\hline \multirow{2}{*}{ ED419 } & MIC & 0.100 & MIC & 0.100 & MIC & 0.100 & MIC & 0.0075 & & MIC & 0.175 \\
& MBC & 0.300 & MBC & 0.200 & MBC & 0.200 & MBC & 0.0800 & MBC & 0.300 \\
\hline \multirow{2}{*}{ K12 } & MIC & 0.150 & MIC & 0.200 & MIC & 0.300 & MIC & 0.0075 & & MIC & 0.175 \\
& MBC & 0.400 & MBC & 0.400 & MBC & 0.400 & MBC & 0.0400 & & MBC & 0.300 \\
\hline
\end{tabular}

$\overline{\mathrm{MIC}}=$ minimal inhibitory concentration, $\mathrm{MBC}=$ minimal bactericidal concentration. 
As reported in previous papers $[6,16,19,30,34,36,37]$, all EOs used in this study had an inhibitory effect on the planktonic growth of E. coli O157:H7, with some differences in strength of action. In addition, we reported that $C$. verum bark EO had a bactericidal effect on all strains used at a very low concentration (between $0.02 \%$ and $0.08 \% v / v$ ), a finding supported by the work of Sheng et al. [6] where C. verum EO was found to be bactericidal on E. coli $\mathrm{O} 157: \mathrm{H7}$ at $0.05 \%(v / v)$. Chloramphenicol and kanamycin, used as reference controls for the tested bacteria, showed a value of MIC of 4 and $8 \mu \mathrm{g} / \mathrm{mL}$ in all strains, respectively (data not shown).

E. coli is a part of gut/intestinal microbiota, with the ability to form biofilm on abiotic and biotic surfaces. To investigate the effect of EOs on the ability of bacteria to form biofilm we used the EOs at the subinhibitory concentration of $0.05 \%(v / v)$ (the cinnamon bark EO at $0.005 \%(v / v))$. Figure 1 showed that all strains were greatly inhibited in their capacity to form biofilm on polystyrene plates, with a percentage of inhibition between $55 \%$ and nearly $100 \%$. Cymbopogon spp. EOs had the greatest antibiofilm activity against all strains. On the other hand, C. verum bark EO had a more potent bactericidal and antibiofilm effect, since it was used in this study at 10 times lower concentrations. To date, several EOs were reported to have an activity against E. coli O157:H7 [31,38]. Kim et al. [19] investigated the effect of $83 \mathrm{EOs}$ at concentration of $0.005 \%(v / v)$ in Luria-Bertani medium on biofilm formation in E. coli O157:H7 EDL933 strain, including C. citratus, C. martini and cinnamon bark EOs from Cinnamomum cassia (L.) J. Presl. Our results with C. verum bark EO agree with those by Kim et al. [19]; however, with C. citratus and C. martini EOs we obtained a greater inhibition, probably due to the higher concentration we used. Interestingly, the planktonic growth was not affected at the concentrations used in the biofilm assay except for a lesser extent in the presence of $C$. citratus, suggesting that the inhibition of biofilm was not a consequence of the absence of planktonic growth; however, it was due to the antibiofilm activity of EOs.

\subsection{Gene Expression Analysis}

In order to understand the molecular mechanisms behind the inhibitory role of EOs in pathogens, some genes related to biofilm formation and pathogenesis of E. coli were monitored by quantitative real-time PCR. We studied the genes involved in motility ( $\operatorname{csg} \mathrm{A}$, fliA and fim $\mathrm{A})$, virulence (st $x 2$ and eha $\mathrm{A})$, membrane protein synthesis (agn43, omp A and $p g a \mathrm{~A})$ and zinc homeostasis $(y \mathrm{kgM}$ and $z i n \mathrm{~T})$ in the presence of C. martini $\mathrm{EO}$. Indeed, in the literature, the studies on C. martini EO are very limited and, to our knowledge, this is the first gene expression study with this oil. Thus, initially we analyzed gene expression levels of mRNA isolated from cells treated with C. martini EO. As shown in Figure 2, the examined genes were mainly downregulated in the pathogen strains. The genes involved in the virulence are missing in the non-pathogen K12 strain. In our control EDL933 strain all genes were downregulated, as well as in EDB strain, in which only the $p g a \mathrm{~A}$ gene was not differentially expressed. $p g a \mathrm{~A}$ gene belongs to the $p g a \mathrm{ABCD}$ operon which synthesizes the poly- $\beta-1,6-\mathrm{N}$-acetyl-D-glucosamine, essential for the cellular architecture of the E. coli biofilm structure. In particular, this gene codes for the exporter of the PGA protein outside the periplasm space. It is noteworthy that this gene was instead highly expressed in the non-pathogen K12, possibly due to a different role of PGA in biofilm formation on plastic material in E. coli O157:H7 and K12 strains [39]. Interestingly, ompA and st 2 were downregulated in all considered strains. 
EDL933
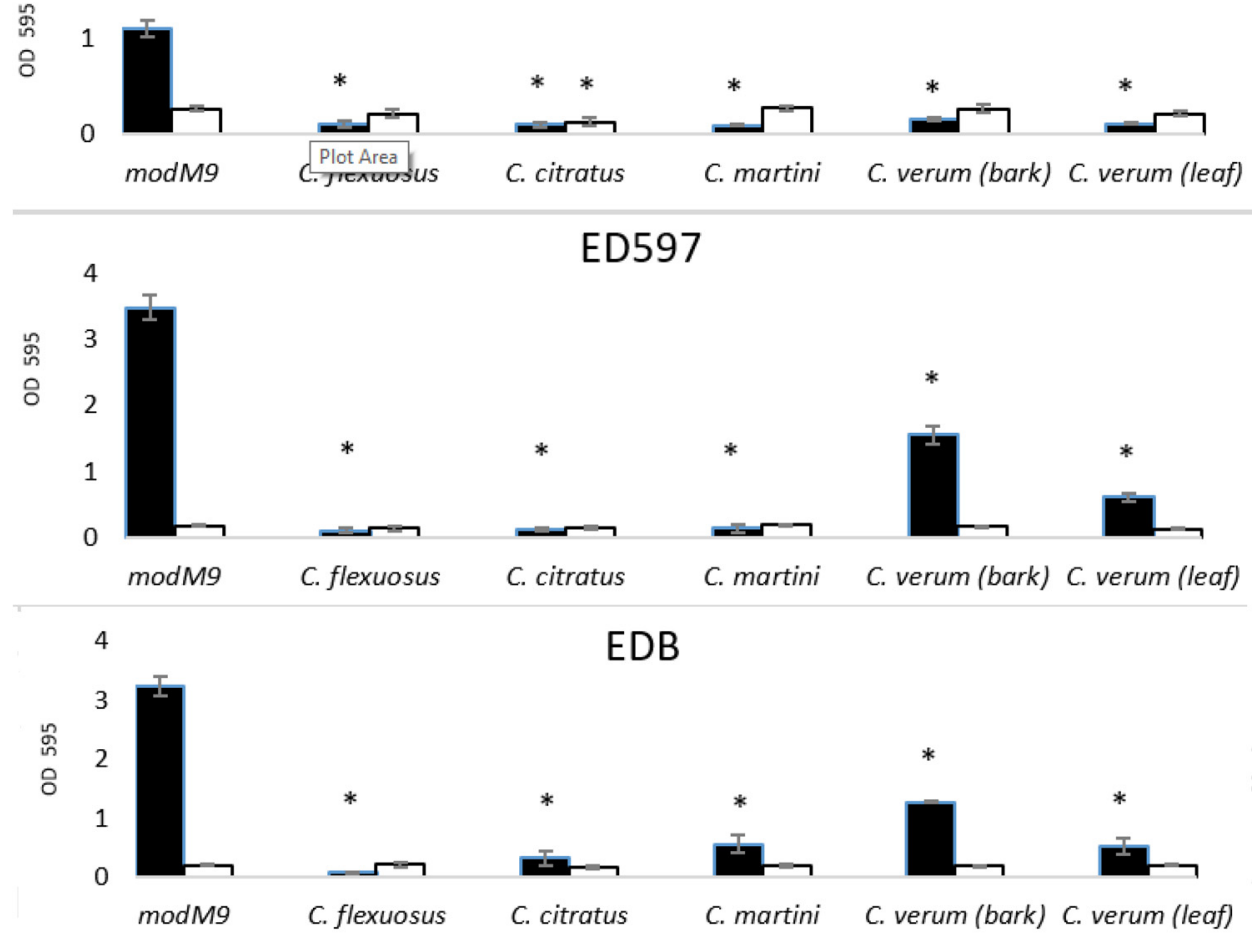

ED419

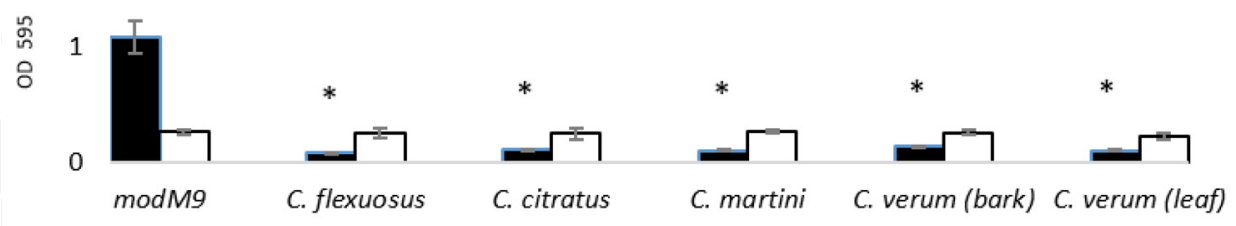

2

K12

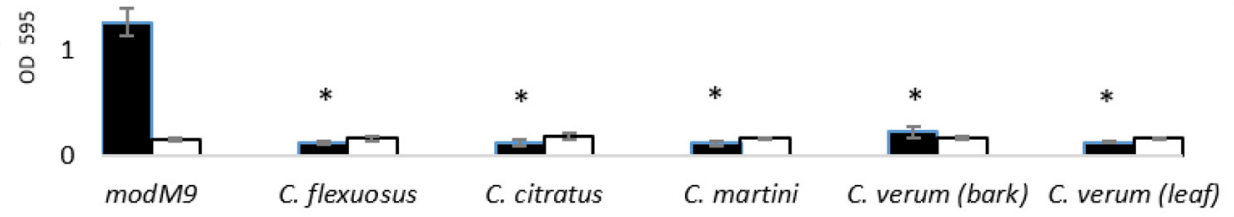

Figure 1. Antibacterial and antibiofilm activity of EOs on E. coli strains. Planktonic growth (white bars) and biofilm formation (black bars) were quantified in modM9 and in modM9 in the presence of EOs, after culture of $24 \mathrm{~h}$ in 96 -well plates, at $28^{\circ} \mathrm{C}$. Data are presented as mean $\pm \mathrm{SD}$ of absorbance (at $595 \mathrm{~nm}) .{ }^{*} p<0.01$. 


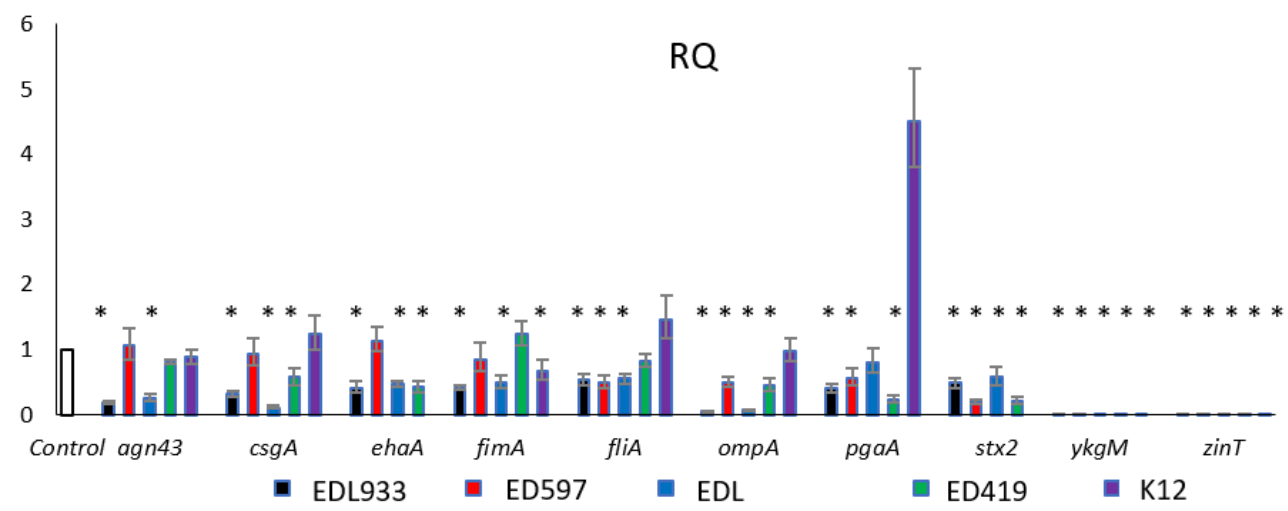

Figure 2. Expression levels of selected genes related to biofilm formation and pathogenesis in E. coli strains treated with or without C. martini EO at $0.05 \%(v / v)$ concentration. Transcriptional profiles were measured by qRT-PCR. * $p<0.01$.

The OmpA is a predominant antigen in the outer membrane, and it can function as an adhesion factor and invasion and serves as a receptor for several bacteriophages. It is known to increase the biofilm formation [40,41] and Barrios et al. [42] demonstrated that ompA mutants formed biofilm of much reduced thickness. Torres et al. [43] described a role as a virulence factor in E. coli O157:H7, which utilized OmpA in adhesion to host cells. Our results demonstrated that $C$. martini $\mathrm{EO}$ repressed ompA expression in all tested pathogen strains grown in the minimal medium M9, indicating that this gene plays a crucial role in the biofilm formation. The st $x 2$ gene codes for the Stx 2 which is an important member of the Shiga toxins family and is associated with the more severe disease in humans. It is a protein essential to the pathogenesis of $E$. coli O157:H7 because, after binding to its receptor, the toxin-receptor complex is internalized. Stx2 production in the gastrointestinal tract, in conjunction with other virulence factors, induces hemorrhagic colitis and its entry into the circulatory system can lead to HUS [6].

In the literature, many works on the effect of EOs on stx repression $[6,30,44,45]$ are reported. Takemasa et al. [46] reported that 20 spices tested, containing eugenol as a main component, were able to reduce Stx production in E. coli O157:H7. However, this is the first study that reported the effect of $C$. martini on stx expression where, using a sublethal concentration of EO, we obtained inhibition of st $x 2$ mRNA expression in all strains examined, except in $\mathrm{K} 12$ where the gene is absent. It is intriguing to note how $z i n \mathrm{~T}$ and $y \mathrm{~kg} \mathrm{M}$ expression was completely repressed in all strains treated with C. martini. Due to the relevant role of these two genes in zinc homeostasis and biofilm formation in zinc-deficient conditions [47], to verify if the other EOs also had the same effect, the $y \mathrm{kgM}$ and zin T expression was examined in cells treated with the other EOs (Figure 3).

Only the $C$. verum leaf EO caused an extensive downregulation of the two genes, as observed with $C$. martini $\mathrm{EO}$. The $C$. flexuosus, $C$. citratus and $C$. verum bark EOs affected the $z i n \mathrm{~T}$ and $y \mathrm{~kg} \mathrm{M}$ expression to a weaker but significant extent and, unexpectedly, we observed that $z$ in $\mathrm{T}$ gene was induced and $y \mathrm{~kg} \mathrm{M}$ expression was repressed in the EDL933 cells treated with the C. verum bark EO. These contrasting results will require further investigations. Nevertheless, findings from transcription analysis of $z i n \mathrm{~T}$ and $y \mathrm{kgM}$ genes suggested that the antibiofilm activity of tested EOs on E. coli could also be related to the homeostasis of zinc. Moreover, it is known that if the zinc homeostasis is not maintained, a series of effect will take place, including an inhibition of curli formation, bacterial attachment, biofilm formation [47] and Stx toxin production [48]. 


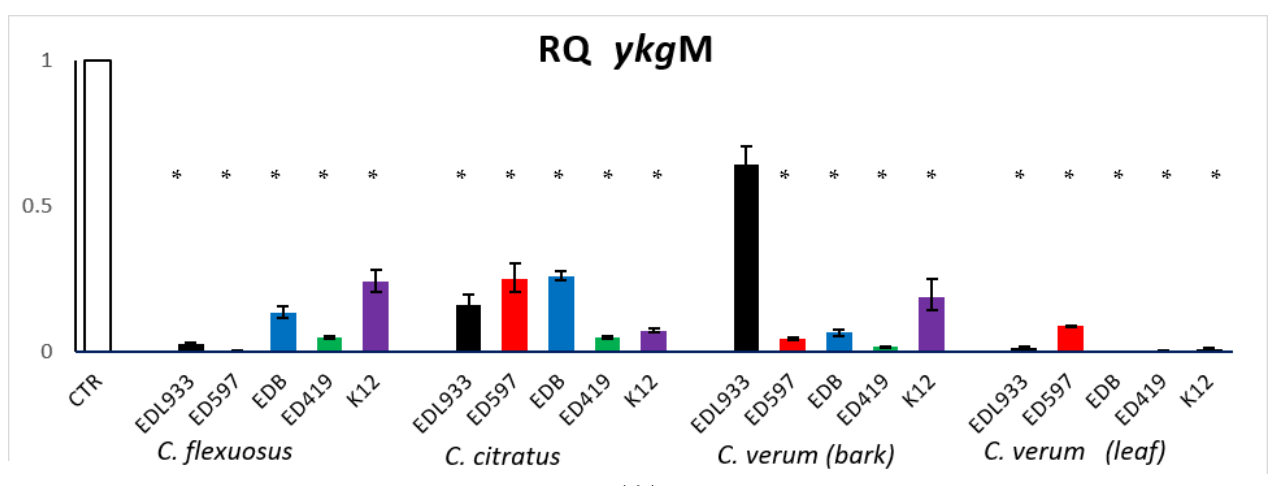

(A)

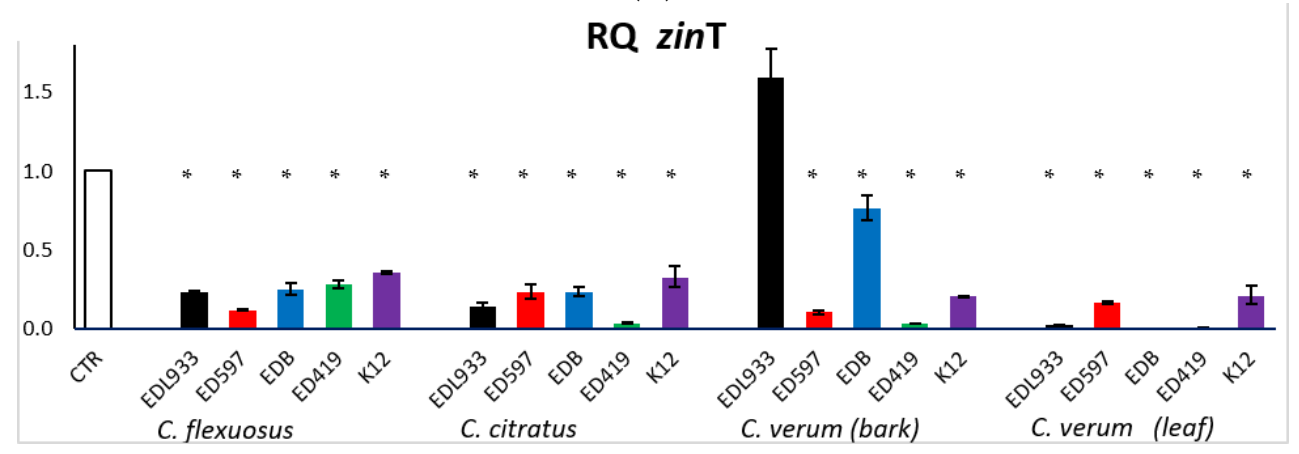

(B)

Figure 3. Transcriptional profiles of $y k g \mathrm{M}(\mathbf{A})$ and $z i n \mathrm{~T}(\mathbf{B})$ in $E$. coli cells treated with or without EOs (CTR), obtained by qRT-PCR. Relative gene expressions represent transcriptional levels after exposure to EOs versus untreated controls. The experiment was performed three times. ${ }^{*} p<0.01$.

\subsection{Scanning Electron Microscope Analysis}

We used the scanning electron microscope (SEM) to observe the shape of E. coli cells and changes in cell morphology under influence of EOs, analyzing the biofilm of all strains with or without treatment with the tested EOs.

The results obtained showed that E. coli O157:H7 strains had a similar behavior, thus in Figure 4 we reported only EDL933, ED597 and the non-pathogen strain. Although this method of investigation does not allow for quantitative assessments, it was evident from the SEM images that the number of cells was higher in modM9 than in strains treated with EOs. In addition, bacteria grown in minimal medium formed a biofilm composed of intact cells, organized in a dense multilayer structure, embedded in a rich matrix network of polysaccharide material (Figure $4 \mathrm{~A}, \mathrm{D}, \mathrm{G}$ ). In accordance with the results of inhibition biofilm assay in presence of EOs, the cells exhibited unorganized biofilm cells, scattered and interconnected by a sparse network (Figure 4B,C,E,F,H,I). SEM observations showed considerable morphological alterations in cells treated with C. flexuosus EO (Figure 4C,F,I), similar to those observed with $C$. citratus EO (data not shown). In fact, the biofilm of each strain grown in modM9 was composed of rod-shaped cells, smooth, swollen and structured in a multilayer. In the presence of $C$. flexuosus or $C$. citratus EOs, the entire organization of the biofilm was altered, and the single cells appeared with evident morphological changes, becoming very elongated with loss of turgidity. SEM micrographs of biofilm obtained in the presence of C. martini and C. verum EOs (only data for C. martini EO are shown) highlighted sparse micro-colonies and individual cells with fewer and shorter interconnecting meshes between cells, but without evident morphological alterations (Figure 4B,E,H). 
EDL933

ED597

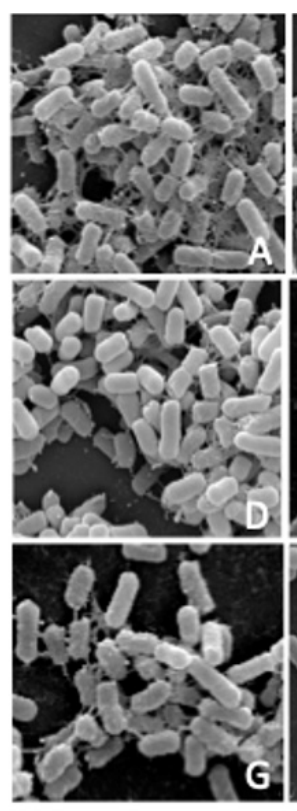

$\operatorname{modM9}$
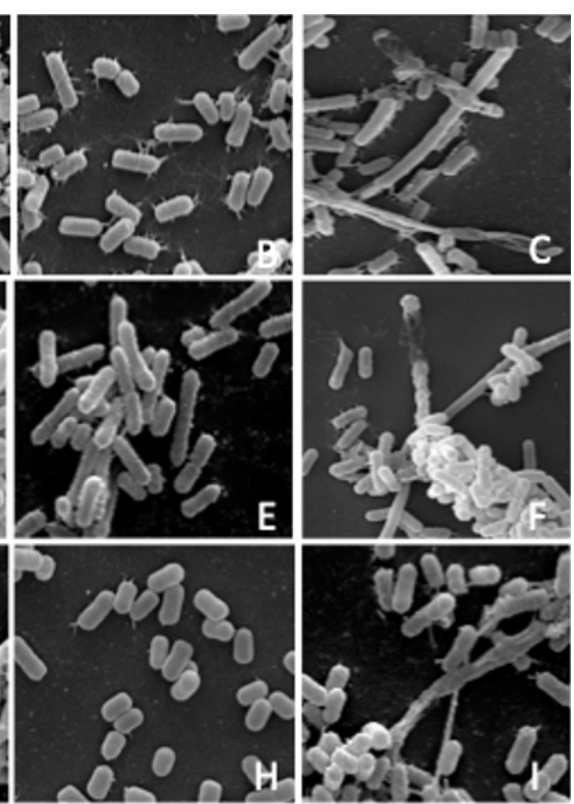

C. martini $\mathrm{EO}$

Figure 4. Effect of C. martini (B,E,H) and C. flexuosus $(\mathbf{C}, \mathbf{F}, \mathbf{I})$ EOs on biofilm formation by E. coli strains (EDL933 strain A-C, ED597 strain D-F, K12strain G-I). Scanning electron microscope (SEM) was used to examine biofilm cells grown on glass coverslips in modM9 in the presence $(\mathbf{B}, \mathbf{C}, \mathbf{E}, \mathbf{F}, \mathbf{H}, \mathbf{I})$ or absence $(\mathbf{A}, \mathbf{D}, \mathbf{G})$ of EOs for $24 \mathrm{~h}$ (magnification $5000 \times$ ).

\subsection{EOs Antibacterial Activity in the Nematode Model}

Nematode lifespan was monitored in the presence and in absence of the tested EOs to evaluate their potential toxic effects on C. elegans vitality. The graph in Figure 5A showed how treatment with the tested EOs did not significantly affect the lifespan of the nematodes, indicating that the EOs did not exert a negative effect, contrary to the report by Kumaran et al. [49] on C. martini EO. Subsequently, the nematode lifespan was used as a parameter to evaluate if the treatment with EOs could inhibit the E. coli O157:H7 virulence $[19,20]$. Figure 5B shows how untreated EDL933 significantly reduced (15 days) the lifespan of nematodes compared with the 21 days of treated EDL933 and the negative control (E. coli OP50). These results, obtained in the nematode in vivo model, demonstrated for the first time that $C$. flexuosus, $C$. citratus and C. martini EOs, as well as $C$. verum EOs, were able to attenuate the EDL933 virulence. Chou et al. [50] demonstrated that $s t x 1$ was required for full toxicity of E. coli O157:H7 in C. elegans. In agreement with previous results of repression of $s t x$ by EOs [6,19] it was possible that the tested EOs reduced the lifespan of C. elegans repressing the expression of stx 1 , with a similar effect demonstrated for $C$. verum EO by Erfan et al. [51]. The study of the expression of stx 1 in presence of Cymbopogon spp. and C. verum EOs will be able to provide new insights into the mode of action of these EOs. 


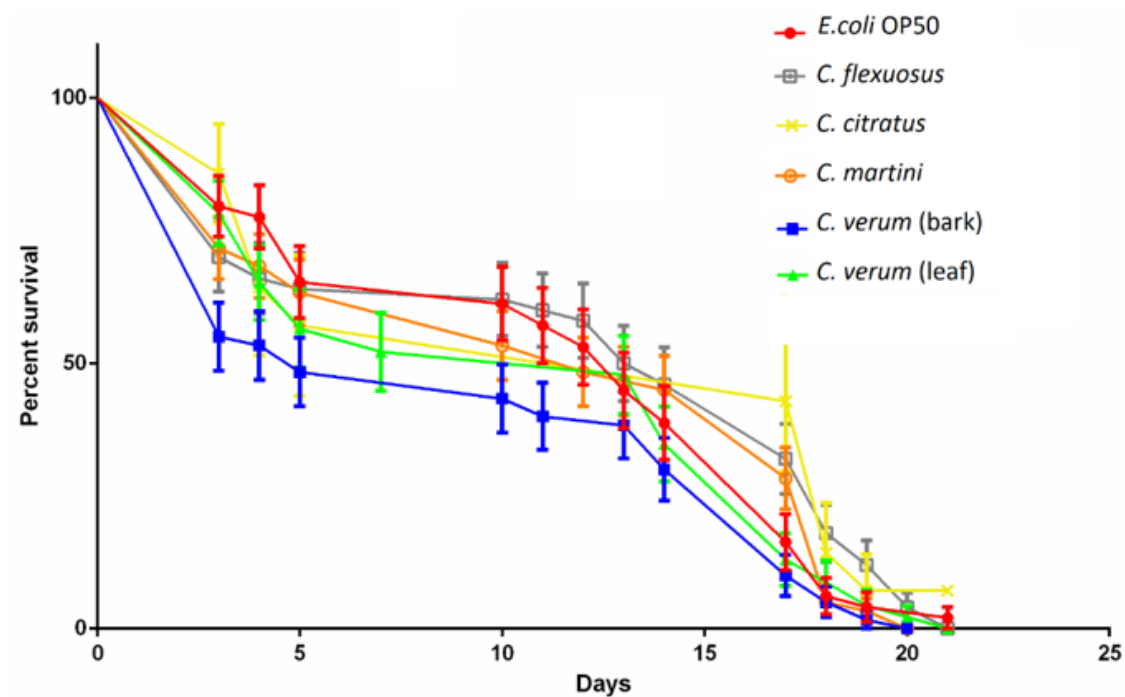

(A)

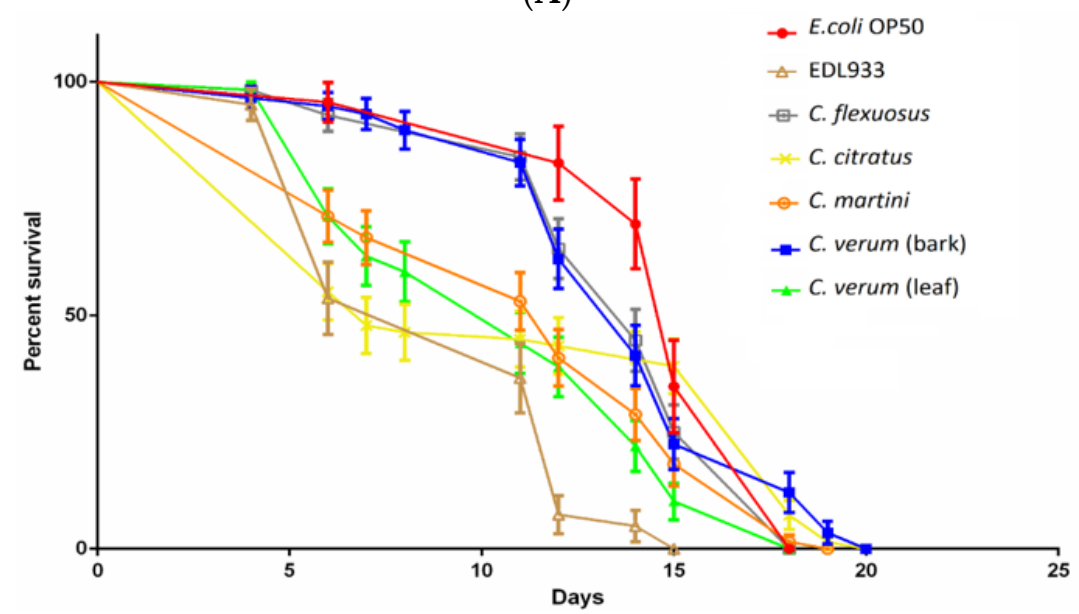

(B)

Figure 5. (A) Effect of EOs on survival of C. elegans infected with E. coli OP 50. Nematodes infected with OP 50 without oil were used as control. (B) Effect of EOs on the survival of C. elegans infected with EDL933. Nematodes infected with E. coli OP 50 and EDL933 in the absence of EOs were used as controls. The experiment was performed three times.

\section{Materials and Methods}

\subsection{Essential Oils}

Commercial EOs used in this study were from lemongrass (C. flexuosus and C. citratus), palmarosa (C. martini) and cinnamon bark and leaf (C. verum). They were purchased from Naissure Traiding (Neath, Dyfes, UK). EOs were stored at $4{ }^{\circ} \mathrm{C}$ and in the dark until use. The EOs quality control for antibacterial activity was tested before the experiments. EOs were streaked onto an LB agar plate and the absence of colonies after the incubation of $24 \mathrm{~h}$ at $37^{\circ} \mathrm{C}$ confirmed the EOs sterility. To prepare a $10 \%(v / v)$ stock solution of EOs, $50 \mu \mathrm{L}$ of EO were dissolved in $450 \mu \mathrm{L}$ of dilution buffer (10\% DMSO, 0.5\% Tween 80 in PBS) before using.

\subsection{Gas Chromatography-Mass Spectrometry (GC-MS) Analysis}

The chemical compositions of the EOs were analyzed by gas chromatography-mass spectrometry (GC-MS) using an Agilent $6890 \mathrm{~N}$ chromatograph coupled with a single quadrupole Agilent $5973 \mathrm{~N}$. The injection was achieved by an autosampler Agilent 7863. The mobile phase was helium (99.999\%) whereas the stationary phase was an HP-5MS $(30 \mathrm{~m} \times 0.25 \mathrm{~mm}, 0.1 \mu \mathrm{m}$ i.d.) capillary column from Agilent. The analytical conditions, 
including injection, split mode, temperature program, scan mode, as well as the identification and quantification of components, were the same as those reported by Maggi et al. [52] and Ornano et al. [53].

\subsection{Bacterial Strains}

In this study, all in vitro tests were performed using the E. coli O157:H7 reference strain EDL933 and three clinical human isolates (ED597, EDB and ED419), belonging to our laboratory collection [54]. As a non-pathogen, E. coli K12 reference strain MG1655 was used. The cultures were obtained by diluting with minimal medium modM9 [55] and measuring OD at $595 \mathrm{~nm}$ to obtain a reading of $0.05-0.07$, giving a standardized inoculum of $1 \times 10^{6} \mathrm{CFU} / \mathrm{mL}$. To prepare the modM9 as well as other zinc-free solutions, ultra-pure water produced by a reverse osmosis system characterized by conductivity lower than $0.03 \mu_{\mathrm{S}} / \mathrm{cm}$ was used. Moreover, bacterial culture and all solutions used with modM9 were prepared, incubated using zinc-free materials and controlled as described by Gabbianelli et al. [55].

\subsection{MIC and MBC Assay}

All used strains were grown in the modM9 in the presence of EOs, and their growth in modM9 was used as control. An overnight inoculum was added to modM9 at the final concentration of $1 \times 10^{6} \mathrm{CFU} / \mathrm{mL}$ in a total volume of $200 \mu \mathrm{L}$ and inoculated in triplicate in a 96-wells polystyrene plate (Becton Dickinson). For determining the MICs, experiments were performed by the broth microdilution method, adapted from CLSI [56]. Two-fold dilutions of EOs, with additional intermediate dilutions, were made to produce a range of EOs concentrations from 0.018 to $1.2 \%(v / v)$. C. verum bark EO was used at final concentrations about 10 times lower than the other EOs, from $0.001 \%$ to $0.018 \%$ $(v / v)$. Two standard reference antibiotics, chloramphenicol and kanamycin $(32-1 \mu \mathrm{g} / \mathrm{mL})$, were used as reference controls for the tested bacteria and were obtained by twofold microdilution method. The microplate was incubated at $28^{\circ} \mathrm{C}$ with constant agitation for $24 \mathrm{~h}$ and optical density monitored at $595 \mathrm{~nm}$ every hour in a microplate reader (ELX808, BIO-TEK Instruments). Minimal inhibition concentration (MIC) was determined as the lowest concentration of each EO that completely inhibited the growth of planktonic cells. Subcultures of $100 \mu \mathrm{L}$ were taken from the clear wells of the microplate and streaked onto agar LB plate, allowing determination of minimal bactericidal concentration (MBC). These values were determined at the lowest concentration of $\mathrm{EO}$ where no growth was observed. All tests were performed in triplicate.

\subsection{Biofilm Formation Assay}

A static biofilm formation assay was performed in 96-wells polystyrene plates, as previously reported [57]. Briefly, overnight cultures were inoculated in modM9 in the absence or presence of EOs at an initial concentration of $1 \times 10^{6} \mathrm{CFU} / \mathrm{mL}$ in a total volume of $200 \mu \mathrm{L}$, inoculated in 96-wells microplate and incubated at $28^{\circ} \mathrm{C}$ for $24 \mathrm{~h}$. Different subinhibitory concentrations of EOs, ranging from 0.1 to $0.05 \%(v / v)$, were added to cultures. C. verum bark EO has been used at a concentration 10 times lower, ranging from 0.01 to $0.005 \%(v / v)$. To quantify total biofilm formation, cell cultures were washed three times with PBS, to remove non-adhered cells, and air dried for $1 \mathrm{~h}$. Biofilm was stained with $0.1 \%$ crystal violet for $20 \mathrm{~min}$ and rinsed three times with tap $\mathrm{H}_{2} \mathrm{O}$, extracted with DMSO and absorbance measured at $595 \mathrm{~nm}$. Results are the average of at least nine replicates.

\subsection{Scanning Electron Microscopy (SEM)}

Scanning electron microscopy (SEM) was used to assess the morphological effects on biofilm formed by E. coli in presence of EOs at $0.025 \%(v / v)$, the minimal subinhibitory concentration that allowed the biofilm formation on glass coverslips, while showing the damages. Both untreated and treated biofilms were obtained as described in our previous work [57]. Briefly, biofilms formed on coverslips of $12 \mathrm{~mm}$ diameter were fixed with $2.5 \%$ 
glutaraldehyde in $0.1 \mathrm{~g} / \mathrm{L}^{-1}$ sodium cacodylate buffer, $\mathrm{pH} 7.4$ at room temperature for $30 \mathrm{~min}$. The fixed cells were then washed three times with the same buffer and post fixed with $1 \%$ osmium tetroxide for three weeks at $4{ }^{\circ} \mathrm{C}$. These samples were washed twice with cacodylate buffer and then dehydrated using a graded alcohol series. After the passage in $100 \%$ ethanol, the samples were critical point-dried in $\mathrm{CO}_{2}$ (CPD 030 Blazers device, Bal-Tec, Blazers) and gold coated by sputtering (SCD 040 Blazers device, Bal-Tec). The samples were examined with a scanning electron microscope FEI Quanta Inspect FEG, (FEI, Hillsboro, OR, USA).

\subsection{RNA Isolation and Quantitative Real-Time RT-PCR}

To isolate the RNA, the strains were inoculated in $8 \mathrm{~mL}$ of $\operatorname{modM} 9$, at the initial concentration of $1 \times 10^{7} \mathrm{CFU} / \mathrm{mL}$ in the presence or absence of EOs, used at a sublethal concentration $(0.05 \%(v / v)$ for $C$. flexuosus, C. citratus, C. martini and C. verum leaf EOs and $0.005 \%(v / v)$ for $C$. verum bark EO) with no inhibitory effect on bacterial growth Cultures were incubated at $28^{\circ} \mathrm{C}$ for $24 \mathrm{~h}$ with $250 \mathrm{rpm}$ agitation and stabilized with RNA Protect Bacteria Reagent (Qiagen). RNA extraction was performed using Presto mini-RNA Bacteria kit (Geneaid), DNA contamination was eliminated using DNase I (Epicentre) for $20 \mathrm{~min}$ at $37^{\circ} \mathrm{C}$ and RNA was precipitated with $0.7 \%$ isopropanol and $0.3 \mathrm{M}$ sodium acetate. The absence of residual DNA was verified by PCR using specific primers. The quantity and the integrity of RNA were determined using a UV-VIS one-drop micro-volume spectrophotometer (DeNovix-Resnova) at $260 \mathrm{~nm}$. RT-PCR was used to investigate the transcription levels of genes involved in motility ( $\operatorname{csg} \mathrm{A}$, fliA and fim $\mathrm{A})$, virulence (st $x 2$ and eha $\mathrm{A})$, synthesis of membrane proteins (agn43, omp A and $p g a \mathrm{~A})$ and zinc homeostasis $(\mathrm{ykgM}$ and $z$ in T) in E. coli treated with or without EO of C. martini $0.05 \%(v / v)$. The expression of $y \mathrm{kgM}$ and $z i n \mathrm{~T}$ genes was analyzed also using the other EOs at the concentration of $0.05 \%$ $(v / v)$ except for the C. verum bark EO which was used at $0.005 \%(v / v)$. To perform RT-PCR a SYBR green kit (Luna Universal One-Step RT-qPCR, BioLabs) was used. The PCR cycling conditions were as follows: cDNA synthesis at $55^{\circ} \mathrm{C}$ for $10 \mathrm{~min}$; denaturation program of $95^{\circ} \mathrm{C}$ for $1 \mathrm{~min}$; amplification and quantification repeated for 40 times $\left(95^{\circ} \mathrm{C}\right.$ for $10 \mathrm{~s}$ and $60{ }^{\circ} \mathrm{C}$ for $30 \mathrm{~s}$ ). The specificity of PCR was determined with melting curve analyses $\left(55^{\circ}\right.$ to $95^{\circ} \mathrm{C}$ with a heating rate of $0.3^{\circ} \mathrm{C} / \mathrm{s}$ ). Forward and reverse primers (Table 3 ) for the analyzed genes were designed using Pel Primer software. To determine the efficiency of each primer pair, a series of five ten-fold dilutions were performed, and standard curves were generated. $R 2$ values, or correlation coefficients $>0.95$ were considered an optimal correlation between values. The $16 \mathrm{~s}$ rRNA, a housekeeping gene, was used to normalize the levels of target gene expression detected between treated and untreated strains by measuring the changes in fold expression using the 2- $\Delta \Delta C T$ method [58]. Bacteria without treatments were used as calibrator sample (control sample). All RT-PCR experiments were conducted at least in triplicate.

Table 3. Primers used in this study for reverse transcription-quantitative PCR.

\begin{tabular}{|c|c|}
\hline Oligo Name & Sequence $5^{\prime}-3^{\prime}$ \\
\hline ant $43 \mathrm{~F} / \mathrm{R}$ & ACAAATGGTCGTCAGGTCGT \\
\hline $\operatorname{csg} \mathrm{A} \mathrm{F} / \mathrm{R}$ & $\begin{array}{l}\text { CCCGTATACGAGTTGTCAGA } \\
\text { GCTCAATCGATCTGACCCAA }\end{array}$ \\
\hline ehaA F/R & $\begin{array}{l}\text { TTACCAAAGCCAACCTGAGT } \\
\text { CAGCCGTTTGTAGAAGTGAA }\end{array}$ \\
\hline fim A F/R & $\begin{array}{l}\text { GCAGAGGTGTCATTATATCCC } \\
\text { CGTTCAGTTAGGACAGGTTC }\end{array}$ \\
\hline$f l i \mathrm{~A} F / \mathrm{R}$ & $\begin{array}{l}\text { TTATTCAGGGTTGTTTGCTCA } \\
\text { GTAAGTTGTAAATGCCGTTCC }\end{array}$ \\
\hline
\end{tabular}


Table 3. Cont.

\begin{tabular}{|c|c|}
\hline Oligo Name & Sequence $5^{\prime}-3^{\prime}$ \\
\hline$p g a \mathrm{~A} F / \mathrm{R}$ & $\begin{array}{c}\text { GCTGAAGGTGTAATGGATAAAC } \\
\text { AGGGACTGCGCATTGATTAC }\end{array}$ \\
\hline$o m p$ A F/R & $\begin{array}{l}\text { GTTCACGTTCGACAACATCG } \\
\text { GTTGTAAGCGTCAGAACCGA }\end{array}$ \\
\hline stx $2 \mathrm{~F} / \mathrm{R}$ & $\begin{array}{l}\text { ACAGACCAAGCACTTCACTC } \\
\text { CGTTCCGGAATGCAAATCAG }\end{array}$ \\
\hline$y k g \mathrm{M} \mathrm{F} / \mathrm{R}$ & $\begin{array}{l}\text { GCGTCATCGTATACACAGGA } \\
\text { TACTGTGGTGTTCCACGACACC }\end{array}$ \\
\hline $\operatorname{zinT} \mathrm{F} / \mathrm{R}$ & $\begin{array}{c}\text { CCTGTATAGAACGGGTGCGATT } \\
\text { ACGGCAAACCCTTAACAGA }\end{array}$ \\
\hline $16 \mathrm{~s} \mathrm{~F} / \mathrm{R}$ & $\begin{array}{c}\text { CTCCATCCCAGTCACTGAG } \\
\text { CATCCACAGAACTTTCCAGAG } \\
\text { CCAACATTTCACAACACGAG }\end{array}$ \\
\hline
\end{tabular}

\subsection{Caenorhabditis Elegans Killing Assay}

The in vivo antibacterial activity of EOs was tested on the C. elegans model system. Wild-type nematodes (N2 strain) were cultivated in Petri dishes containing nematode growth media (NGM) agar and a food source consisting of E. coli OP50 grown as a superficial monolayer. The nematodes were synchronized to obtain a colony of individuals at the same larval stage. First, 24-wells plates, containing $1 \mathrm{~mL}$ of NGM each well were prepared with $100 \mu \mathrm{M}$ of ampicillin to avoid bacterial contaminations and $40 \mathrm{mM}$ of 5-fluoro-2'-deoxyuridine (FUDR) to obtain sterile nematode was added to NGM agar. In order to evaluate the potentially toxic effects of EOs on C. elegans vitality, $50 \mu \mathrm{L}$ of E. coli OP50 liquid culture were seeded into each well and incubated overnight at $37^{\circ} \mathrm{C}$ to obtain a bacterial monolayer, with $50 \mu \mathrm{L}$ of $0.05 \%(v / v)$ of $C$. flexuosus, C. citratus, C. martini and C. verum leaf EOs and $0.005 \%(v / v)$ of $C$. verum bark EO added to each well. Moreover, to assess the effects of EOs on E. coli O157:H7 ability to kill the nematode, an inoculum of $1 \times 10^{6} \mathrm{CFU} / \mathrm{mL}$ of EDL933 strain was grown overnight at $28^{\circ} \mathrm{C}$ in the modM9 in the absence or presence of EOs and $50 \mu \mathrm{L}$ of the treated and untreated inoculate containing EDL933 were added to each well of the dedicated plate. No treatment was applied to the negative control dedicated plate where E. coli OP50 was added. After preparing the 24-wells plates as described above, about 40 synchronized L4/young adult nematodes were transferred into plates (four nematodes for well) and scored as dead or alive on a daily basis by gently touching them with a platinum wire. Three independent experiments were conducted (approximately $100 \mathrm{~L} 4$ /young adult nematodes tested for each treatment).

\subsection{Statistical Analysis}

Experiments were performed in triplicate and repeated for at least three times $(n=9)$. Results were presented as average \pm the standard deviations, and statistically significant differences $(p<0.01)$ were determined by Student's t-test using Excel software (Microsoft Office Excel 2016). C. elegans killing assay statistical analysis was performed by long-rank test (Mantel-Cox) [59].

\section{Conclusions}

EOs extracted from aromatic plants of commercial interest possess strong antimicrobial activity and the findings of this study support previous reports on the effect of EOs. The results emerged from this study demonstrated that EOs can inhibit bacterial growth and reduce the ability to form a biofilm. The EOs from C. verum and Cymbopogon species demonstrated to be effective against several pathogen E. coli O157:H7 strains. Particularly, C. martini $\mathrm{EO}$ interferes with the expression of genes that are directly or indirectly responsible for the formation of biofilm and genes implicated in the pathogenesis. Furthermore, 
the present study suggests that the activity of also EOs involves the homeostasis of zinc and confirms a possible action on the cellular membrane. In conclusion, we confirm the usefulness of EOs as promising alternative candidates to current antimicrobials in the $\mathrm{EHCH}$ infections, mainly due to the SOS response and production of Shiga toxin induced by antibiotics. On the contrary, EOs appear to reduce the expression of $s t x$, which is the trigger for the onset of HUS. However, due to the complex action displayed by EOs, further research is needed to elucidate the molecular mechanisms underlying the noteworthy antibacterial activity in order to support their future exploitation as natural antibiofilm agents. The main limitation in the use of EOs as antimicrobial agents is due to their complex composition, which depends on various factors (i.e., extraction method, geographical area of origin etc.) which entails the need for accurate control of the individual batches.

Supplementary Materials: The following are available online at https: / www.mdpi.com/2079-6 382/10/2/113/s1, Figure S1: GC-MS chemical profiles of the five essential oils investigated for the antibiofilm activity, Table S1: Chemical composition (\%) of essential oils.

Author Contributions: Conceptualization and methodology, R.S., A.S., L.N., M.Z., P.B., F.M. and R.G.; formal analysis, R.S., A.S., L.N., M.Z., P.B., F.M. and R.G.; data curation, R.S., A.S., L.N., M.Z., P.B., F.M. and R.G.; writing-original draft preparation, R.S. and R.G.; writing-review and editing, F.M. and L.N.; visualization, F.M., R.S. and R.G.; supervision, R.G. and R.S. All authors have read and agreed to the published version of the manuscript.

Funding: This research received no external funding but was financially supported by the Italian National Institute of Health.

Data Availability Statement: Data available on request.

Acknowledgments: The authors also thank Maria Grazia Berardinelli and Elena Sturchio, Department of Technological Innovation and Safety of Plants, Product and Anthropic Settlements (DIT), Italian Workers' Compensation Authority (INAIL), for their scientific support.

Conflicts of Interest: The authors declare no conflict of interest.

\section{References}

1. Elcock, E.R.; Spencer-Phillips, P.T.N.; Adukwu, E.C. Rapid bactericidal effect of cinnamon bark essential against Pseudomonas aeruginosa. J. Appl. Microbiol. 2019, 128, 1025-1037. [CrossRef] [PubMed]

2. Flemming, H.C.; Wingender, J.; Szewzyk, U.; Steinberg, P.; Rice, S.A.; Kjelleberg, S. Biofilm, an emergent form of bacterial life. Nat. Rev. Microbiol. 2016, 14, 563-575. [CrossRef] [PubMed]

3. Hall, C.W.; Mah, T.F. Molecular mechanisms of biofilm-based antibiotic resistance and tolerance in pathogenic bacteria. FEMS Microbiol. Rev. 2017, 41, 276-301. [CrossRef] [PubMed]

4. Bridier, A.; Briandet, R.; Thomas, V.; Dubois-Brissonnet, F. Resistance of bacterial biofilms to disinfectants: A review. Biofouling 2011, 27, 1017-1032. [CrossRef] [PubMed]

5. Paton, J.C.; Paton, A.W. Pathogenesis and diagnosis of Shiga toxin-producing Escherichia coli Infections. Clin. Microbiol. Rev. 1998, 11, 450-479. [CrossRef] [PubMed]

6. Sheng, L.; Rasco, B.; Zhu, M.J. Cinnamon Oil Inhibits Shiga Toxin Type 2 Phage Induction and Shiga Toxin Type 2 Production in Escherichia coli O157:H7. Appl. Environ. Microbiol. 2016, 82, 6531-6540. [CrossRef] [PubMed]

7. Chouhan, S.; Sharma, K.; Guleria, S. Antimicrobial activity of some essential oils-Present status and future perspectives. Medicines 2017, 4, 58. [CrossRef] [PubMed]

8. Nazzaro, F.; Fratianni, F.; De Martino, L.; Coppola, R.; De Feo, V. Effect of essential oils on pathogenic bacteria. Pharmaceuticals 2013, 6, 1451-1474. [CrossRef]

9. Burt, S.A.; Reinders, R.D. Antibacterial activity of selected plant essential oils against Escherichia coli O157:H7. Lett. Appl. Microb. 2003, 36, 162-167. [CrossRef]

10. De Martino, L.; de Feo, V.; Nazzaro, F. Chemical composition and in vitro antimicrobial and mutagenic activities of seven Lamiaceae essential oils. Molecules 2009, 14, 4213-4230. [CrossRef]

11. Raybaudi-Massilia, R.M.; Mosqueda-Melgar, J.; Martin-Belloso, O. Antimicrobial activity of essential oils on Salmonella enteritidis, Escherichia coli, and Listeria innocua in fruit juices. J. Food Prot. 2006, 69, 1579-1586. [CrossRef] [PubMed]

12. Velluti, A.; Sanchis, V.; Ramos, A.J.; Egido, J.; Marın, S. Inhibitory effect of cinnamon, clove, lemongrass, oregano and palmarose essential oils on growth and fumonisin B1 production by Fusarium proliferatum in maize grain. Int. J. Food Microbiol. 2003, 89, 145-154. [CrossRef] 
13. Tariq, S.; Wani, S.; Rasool, W.; Shafi, K.; Bhat, M.A.; Prabhakar, A.; Shalla, A.H.; Rather, M.A. A comprehensive review of the antibacterial, antifungal and antiviral potential of essential oils and their chemical constituents against drug-resistant microbial pathogens. Microb. Pathog. 2019, 134, 103580. [CrossRef] [PubMed]

14. Mutlu-Ingok, A.; Devecioglu, D.; Dikmetas, D.N.; Karbancioglu-Guler, F.; Capanoglu, E. Antibacterial, Antifungal, Antimycotoxigenic, and Antioxidant Activities of Essential Oils: An Updated Review. Molecules 2020, 25, 4711. [CrossRef] [PubMed]

15. Thapa, D.; Louis, P.; Losa, R.; Zweifel, B.; Wallace, R.J. Essential oils have different effects on human pathogenic and commensal bacteria in mixed faecal fermentations compared with pure cultures. Microbiology 2015, 161, 441-449. [CrossRef] [PubMed]

16. Mith, H.; Duré, R.; Delcenserie, V.; Zhiri, A.; Daube, G.; Clinquart, A. Antimicrobial activities of commercial essential oils and their components against food-borne pathogens and food spoilage bacteria. Food Sci. Nutr. 2014, 2, 403-416. [CrossRef] [PubMed]

17. Si, W.; Gong, J.; Tsao, R.; Zhou, T.; Yu, H.; Poppe, C.; Johnson, R.; Du, Z. Antimicrobial activity of essential oils and structurally related synthetic food additives towards selected pathogenic and beneficial gut bacteria. J. Appl. Microbiol. 2006, 161, 296-305. [CrossRef] [PubMed]

18. Kim, S.Y.; Kang, D.H.; Kim, J.K.; Ha, J.G.; Hwang, J.Y.; Kim, T.; Lee, S.H. Antimicrobial activity of plant extracts against Salmonella Typhimurium, Escherichia coli O157:H7, and Listeria monocytogenes on fresh lettuce. J. Food Sci. 2011, 76, M41-M46. [CrossRef]

19. Kim, Y.G.; Lee, J.H.; Gwon, G.; Kim, S.I.; Park, J.G.; Lee, J. Essential Oils and Eugenols Inhibit Biofilm Formation and the Virulence of Escherichia coli O157:H7. Sci. Rep. 2016, 6, 36377. [CrossRef]

20. Lee, J.H.; Kim, Y.G.; Cho, H.S.; Ryu, S.Y.; Cho, M.H.; Lee, L. Coumarins reduce biofilm formation and the virulence of Escherichia coli O157:H7. Phytomedicine 2014, 21, 1037-1042. [CrossRef]

21. Maggi, F.; Fortuné Randriana, R.; Rasoanaivo, P.; Nicoletti, M.; Quassinti, L.; Bramucci, M.; Lupidi, G.; Petrelli, D.; Vitali, L.A.; Papa, F.; et al. Chemical composition and in vitro biological activities of the essential oil of Vepris macrophylla (Baker) I. Verd. endemic to Madagascar. Chem. Biodivers. 2013, 10, 356-366. [CrossRef] [PubMed]

22. Oliveira, M.A.C.; Borges, A.C.; Brighenti, F.L.; Salvador, M.J.; Gontijo, A.V.L.; Koga-Ito, C.Y. Cymbopogon citratus essential oil: Effect on polymicrobial caries-related biofilm with low cytotoxicity. Braz. Oral Res. 2017, 31, e89. [CrossRef] [PubMed]

23. Helander, I.M.; Alakomi, H.L.; Latva-Kala, K.; Mattila-Sandholm, T.; Pol, I.; Smid, E.J.; Gorris, L.G.M.; von Wrigh, A. Characterization of the Action of Selected Essential Oil Components on Gram-Negative Bacteria. J. Agric. Food Chem. 1998, 46, $3590-3595$. [CrossRef]

24. Brnawi, W.I.; Hettiarachchy, N.S.; Horax, R.; Kumar-Philips, G.; Seo, H.S.; Marcy, J. Comparison of Cinnamon Essential Oils from Leaf and Bark with Respect to Antimicrobial Activity and Sensory Acceptability in Strawberry Shake. J. Food Sci. 2018, 83, 475-480. [CrossRef]

25. Giamperi, L.; Bucchini, A.E.A.; Ricci, D.; Tirillini, B.; Nicoletti, M.; Rakotosaona, R.; Maggi, F. Vepris macrophylla (Baker) I. Verd Essential Oil: An Antifungal Agent against Phytopathogenic Fungi. Int. J. Mol. Sci. 2020, 21, 2776. [CrossRef] [PubMed]

26. Laekeman, G.M.; van Hoof, L.; Haemers, A.; Vanden Berghe, D.A.; Herman, A.G.; Vlietinck, A.J. Eugenol a valuable compound for in vitro experimental research and worthwhile for further in vivo investigation. Phytother. Res. 1990, 4, 90-96. [CrossRef]

27. Ouattara, B.; Simard, R.E.; Holley, R.A.; Piette, G.J.; Bégin, A. Antibacterial activity of selected fatty acids and essential oils against six meat spoilage organisms. Int. J. Food Microbiol. 1997, 37, 155-162. [CrossRef]

28. Kim, J.; Marshall, M.R.; Wei, C. Antibacterial Activity of Some Essential Oil Components against Five Foodborne Pathogens. J. Agric. Food Chem. 1995, 43, 2839-2845. [CrossRef]

29. Guimarães, A.C.; Meireles, L.M.; Lemos, M.F.; Guimarães, M.C.C.; Endringer, D.C.; Fronza, M.; Scherer, R. Antibacterial Activity of Terpenes and Terpenoids Present in Essential Oils. Molecules 2019, 24, 2471. [CrossRef]

30. Kim, Y.G.; Lee, J.H.; Kim, S.I.; Baek, K.H.; Lee, J. Cinnamon bark oil and its components inhibit biofilm formation and toxin production. Int. J. Food Microbiol. 2015, 195, 30-39. [CrossRef]

31. Ortega-Ramirez, L.A.; Silva-Espinoza, B.A.; Vargas-Arispuro, I.; Gonzalez-Aguilar, G.A.; Cruz-Valenzuela, M.R.; Nazzaro, F.; Ayala-Zavala, J.F. Combination of Cymbopogon citratus and Allium cepa essential oils increased antibacterial activity in leafy vegetables. J. Sci. Food Agric. 2017, 97, 2166-2173. [CrossRef] [PubMed]

32. Firmino, D.F.; Cavalcante, T.T.A.; Gomes, G.A.; Firmino, N.C.S.; Rosa, L.D.; de Carvalho, M.G.; Catunda, F.E.A., Jr. Antibacterial and Antibiofilm Activities of Cinnamomum Sp. Essential Oil and Cinnamaldehyde: Antimicrobial Activities. Sci. World J. 2018, 2018, 7405736. [CrossRef]

33. Vasireddy, L.; Bingle, L.E.H.; Davies, M.S. Antimicrobial activity of essential oils against multidrug-resistant clinical isolates of the Burkholderia cepacia complex. PLoS ONE 2018, 13, e0201835. [CrossRef] [PubMed]

34. Cáceres, M.; Hidalgo, W.; Stashenko, E.; Torres, R.; Ortiz, C. Essential Oils of Aromatic Plants with Antibacterial, Anti-Biofilm and Anti-Quorum Sensing Activities against Pathogenic Bacteria. Antibiotics 2020, 9, 147. [CrossRef] [PubMed]

35. Lee, J.E.; Jung, M.; Lee, S.C.; Huh, M.J.; Seo, S.M.; Park, I.K. Antibacterial mode of action of trans-cinnamaldehyde derived from cinnamon bark (Cinnamomum verum) essential oil against Agrobacterium tumefaciens. Pestic. Biochem. Physiol. 2020, 165, 104546. [CrossRef]

36. Zulfa, Z.; Chia, C.; Rukayadi, Y. In vitro antimicrobial activity of Cymbopogon citratus (lemongrass) extracts against selected foodborne pathogens. Int. Food Res. J. 2016, 23, 1262-1267.

37. Ortega-Ramirez, L.A.; Gutiérrez-Pacheco, M.M.; Vargas-Arispuro, I.; Gonzales- Aguilar, G.A.; Martínez-Téllez, M.A.; AyalaZavala, J.F. Inhibition of Glucosyltransferase Activity and Glucan Production as an Antibiofilm Mechanism of Lemongrass Essential Oil against Escherichia coli O157:H7. Antibiotics 2020, 9, 102. [CrossRef] 
38. Yuan, W.; Yuk, H.G. Effects of Sublethal Thymol, Carvacrol, and trans-Cinnamaldehyde Adaptation on Virulence Properties of Escherichia coli O157:H7. Appl. Environ. Microbiol. 2019, 85, e00271-19. [CrossRef]

39. Matthysse, A.G.; Deora, R.; Mishra, M.; Torres, A.G. Polysaccharides cellulose, poly-beta-1,6-n- acetyl-D-glucosamine, and colanic acid are required for optimal binding of Escherichia coli O157:H7 strains to alfalfa sprouts and K-12 strains to plastic but not for binding to epithelial cells. Appl. Environ. Microbiol. 2008, 74, 2384-2390. [CrossRef]

40. Orme, R.; Douglas, C.W.; Rimmer, S.; Webb, M. Proteomic analysis of Escherichia coli biofilms reveals the overexpression of the outer membrane protein OmpA. Proteomics 2006, 6, 4269-4277. [CrossRef]

41. Qun, M.; Wood, T.K. OmpA influences Escherichia coli biofilm formation by repressing cellulose production through the CpxRA two-component system. Environ. Microbiol. 2009, 11, 2735-2746. [CrossRef]

42. Barrios, A.F.; Zuo, R.; Ren, D.; Wood, T.K. Hha, YbaJ, and OmpA regulate Escherichia coli K12 biofilm formation and conjugation plasmids abolish motility. Biotechnol. Bioeng. 2006, 93, 188-200. [CrossRef] [PubMed]

43. Torres, A.G.; Kaper, J.B. Multiple elements controlling adherence of enterohemorrhagic Escherichia coli O157:H7 to HeLa cells. Infect. Immun. 2003, 71, 4985-4995. [CrossRef] [PubMed]

44. Mith, H.; Clinquart, A.; Zhiri, A.; Daube, G.; Delcenserie, V. The impact of oregano (Origanum heracleoticum) essential oil and carvacrol on virulence gene transcription by Escherichia coli O157:H7. FEMS Microbiol. Lett. 2015, 362, 1-7. [CrossRef]

45. Khatibi, S.A.; Misaghi, A.; Moosavy, M.H.; Akhondzadeh Basti, A.; Mohamadian, S.; Khanjari, A. Effect of nanoliposomes containing Zataria multiflora Boiss. essential oil on gene expression of Shiga toxin 2 in Escherichia coli O157:H7. J. Appl. Microbiol. 2018, 124, 389-397. [CrossRef]

46. Takemasa, N.; Ohnishi, S.; Tsuji, M.; Shikata, T.; Yokoigawa, K. Screening and analysis of spices with ability to suppress verocytotoxin production by Escherichia coli O157:H7. J. Food Sci. 2009, 74, M461-M466. [CrossRef]

47. Lim, J.; Lee, K.M.; Kim, S.H.; Kim, Y.; Kim, S.H.; Park, W.; Park, S. YkgM and ZinT proteins are required for maintaining intracellular zinc concentration and producing curli in enterohemorrhagic Escherichia coli (EHEC) O157:H7 under zinc deficient conditions. Int. J. Food Microbiol. 2011, 149, 159-170. [CrossRef]

48. Crane, J.K.; Broome, J.E.; Reddinger, R.M.; Werth, B.B. Zinc protects against shiga-toxigenic Escherichia coli by acting on host tissues as well as on bacteria. BMC Microbiol. 2014, 14, 145. [CrossRef]

49. Kumaran, A.M.; D'Souza, P.; Agarwal, A.; Bokkolla, R.M.; Balasubramaniam, M. Geraniol, the putative anthelmintic principle of Cymbopogon martini. Phytother. Res. 2003, 17, 957. [CrossRef]

50. Chou, T.C.; Chiu, C.; Kuo, C.J.; Wu, C.M.; Syu, W.J.; Chiu, W.T.; Chen, C.S. Enterohaemorrhagic Escherichia coli O157:H7 Shiga-like toxin 1 is required for full pathogenicity and activation of the p38 mitogen-activated protein kinase pathway in Caenorhabditis elegans. Cell. Microbiol. 2013, 15, 82-97. [CrossRef]

51. Erfan, A.M.; Marouf, S. Cinnamon oil downregulates virulence genes of poultry respiratory bacterial agents and revealed significant bacterial inhibition: An in vitro perspective. Vet. World 2019, 12, 1707-1715. [CrossRef]

52. Maggi, F.; Cecchini, C.; Cresci, A.; Coman, M.M.; Tirillini, B.; Sagratini, G.; Papa, F.; Vittori, S. Chemical composition and antimicrobial activity of the essential oils from several Hypericum taxa (Guttiferae) growing in central Italy (Appennino UmbroMarchigiano). Chem. Biodivers. 2010, 7, 447-466. [CrossRef] [PubMed]

53. Ornano, L.; Venditti, A.; Ballero, M.; Sanna, C.; Quassinti, L.; Bramucci, M.; Lupidi, G.; Papa, F.; Vittori, S.; Maggi, F.; et al. Chemopreventive and antioxidant activity of the chamazulene-rich essential oil obtained from Artemisia arborescens L. growing on the Isle of La Maddalena, Sardinia, Italy. Chem. Biodivers. 2013, 10, 1464-1474. [CrossRef] [PubMed]

54. Scotti, R.; Nicolini, L.; Gabbianelli, R. Sod C genes expression in Escherichia coli O157:H7 strains. Ann. Ist. Super. Sanità 2016, 52, 309-312. [CrossRef]

55. Gabbianelli, R.; Scotti, R.; Ammendola, S.; Petrarca, P.; Nicolini, L.; Battistoni, A. Role of ZnuABC and ZinT in Escherichia coli O157:H7 zinc acquisition and interactior with epithelial cells. BMC Microbiol. 2011, 11, 11-36. [CrossRef] [PubMed]

56. Clinical and Laboratory Standards Institutes (CLSI). Methods for Dilution Antimicrobial Susceptibility Tests for Bacteria that Grow Aerobically, 11th ed.; M07 Ed.11; CLSI: Wayne, PA, USA, 2018.

57. Scotti, R.; Nicolini, L.; Stringaro, A.; Gabbianelli, R. A study on prophagic and chromosomal sodC genes involvement in Escherichia coli O157:H7 biofilm formation and biofilm resistance to $\mathrm{H}_{2} \mathrm{O}_{2}$. Ann. Ist. Super. Sanità 2015, 51, 62-66. [CrossRef]

58. Pfaffl, M.W. A new mathematical model for relative quantification in real-time RT-PCR. Nucleic Acids Res. 2001, 29, e45. [CrossRef]

59. Amrit, F.R.; Ratnappan, R.; Keith, S.A.; Ghazi, A. The C. elegans lifespan assay toolkit. Methods 2014, 68, 465-475. [CrossRef] 